\title{
INHIBITION OF PYOCYANIN PRODUCTION IN PSEUDOMONAS AERUGINOSA BY NATURAL ANTIMICROBIAL COMPOUNDS FROM HERBAL EXTRACTS
}

\author{
PREETI JAIN ${ }^{1}$, SUMAN KUMARI ${ }^{1}$, ASHISH MALIK ${ }^{2 *}$ \\ ${ }^{1}$ Department of Biochemistry, Maharshi Dayanand University, Rohtak, Haryana, India. ${ }^{2}$ Department of Botany, Maharshi Dayanand \\ University, Rohtak, Haryana, India. Email: Ashishmalik31@gmail.com
}

Received: 21 February 2017, Revised and Accepted: 03 April 2017

\section{ABSTRACT}

Objective: Pseudomonas aeruginosa produces a range of metabolites including pyocyanin that enhance its ability to resist antibiotics and becomes capable of surviving adverse conditions.

Methods: In this report, eight plants (extracted with five solvents) were screened for antibacterial activity against $P$. aeruginosa by microbroth dilution method. Afterward tested for inhibition of pyocyanin in presence and absence of plant extracts.

Result: Among these Digera muricata and Solanum quitoense exhibited good antibacterial potential. Inhibition of pyocyanin is identified as a potential anti-virulence strategy. Therefore, acetone extract of six plants exhibited minimum inhibitory concentration (MIC) $\leq 3.125 \mathrm{mg} / \mathrm{ml}$ and methanol extract of three plants exhibited MIC $\leq 6.25 \mathrm{mg} / \mathrm{ml}$ was used to check pyocyanin inhibition in $P$. aeruginosa. In acetone extracts, significant pyocyanin inhibition was found in Ipomoea pesticides and Citrullus colocynthis. In methanol extracts, C. colocynthis and D. muricata showed considerable pyocyanin inhibition.

Conclusion: Overall result indicates that the best antimicrobial compound (growth inhibitor) may not be best inhibitor of pyocyanin biosynthesis or vice-versa. Moreover, I. pesticides, C. colocynthis, and D. muricata seem to contain compounds which inhibit the growth of bacteria as well as the biosynthesis of pyocyanin.

Keywords: Pseudomonas aeruginosa, Pyocyanin, Antibacterial activity, Chloroform extraction assay, Herbal extract.

(C) 2017 The Authors. Published by Innovare Academic Sciences Pvt Ltd. This is an open access article under the CC BY license (http://creativecommons. org/licenses/by/4. 0/) DOI: http://dx.doi.org/10.22159/ajpcr.2017.v10i6.18056

\section{INTRODUCTION}

Pseudomonas aeruginosa is a ubiquitous bacterium involved in numerous pathogenic infections in immunocompromised individuals [1]. P. aeruginosa infection `is difficult to eradicate, due to antibiotic resistance developed with the increased and indiscriminate use of antibiotics [2]. Virulence factors present in P. aeruginosa damage the host tissues and increase the survival ability of this bacterium [3]. Therefore, inhibition of virulence factors has been identified as a potential new therapeutic approach to treat $P$. aeruginosa infections. Inhibition of virulence factors attenuates the pathogenicity of the bacterium, and the host immune system can clear the infection. Pyocyanin is one of the many virulence factors produced by P. aeruginosa. Pyocyanin pigment is a toxin [4] and its biosynthesis is regulated by quorum sensing system of bacteria [5]. Therefore, inhibition of pyocyanin is identified as a potential antivirulence strategy and interest has been developed in the discovery of compounds which inhibit pyocyanin biosynthesis.

Health-care demands new antibacterial agents that are more potent [6]. Herbal medicines have been increasingly recognized as an alternative form of health care, therefore, the screening of medicinal plants for anti-virulence factors compounds is becoming important. Therefore, in this study, Leucas aspera, Ipomoea pesticides, Citrullus colocynthis, Digera muricata, Gomphrena celosioides, Helianthus annuus, Solanum quitoense, and Alternanthera pungens plants were collected (Table 1) and have been screened against $P$. aeruginosa for their antimicrobial activity and pyocyanin biosynthesis inhibition capability.

\section{METHODS}

\section{Chemicals and apparatus}

Chloroform, acetone, sterile distilled water, dimethyl sulfoxide (Hi-media), hydrochloride (HCL), ampicillin, nutrient broth, ethanol, resazurin dye, autoclave (Hicon), laminar flow (Metrex), incubator shaker (Remi), Halo DB 20 spectrophotometer (Dynamica), sphinx vortex shaker (Tarsons), water bath (Hicon), centrifuge (Remi), and 96-well plates.

\section{Microorganism}

Lyophilized culture of P. aeruginosa was obtained from National Dairy Research Institute, Karnal in September 2013. Cultures were revived in nutrient broth and used for antimicrobial microbroth dilution assay and pyocyanin production assay under the influence of antimicrobial extracts.

\section{Plant material}

Eight medicinal plants were collected from the local area and their natural habitat Rohtak, Haryana, India during September 2012 and February 2013 (Table 1). The L. aspera (leaves), I. pesticides (leaves), C. colocynthis (fruit and leaves), D. muricata (leaves), G. celosioides (whole), Helianthus annuus (whole), S. quitoense (leaves), and A. punguins (whole) were collected and identified from Department of Botany, M. D. University, Rohtak (India). Plant identifications were reconfirmed from the flora of Haryana.

\section{Preparation of extracts}

Plant materials were washed with distilled water three times and air dried by keeping in the shade for 3 weeks. The properly dried plant materials were crushed and ground to fine powder. For each plant/plant part, $100 \mathrm{~g}$ of material was extracted consecutively for three times for 72 hrs with five different solvents (100 ml each) in ascending order of polarity, i.e., hexane, chloroform, acetone, methanol, and water. The combined extracts were filtered, and solvents were evaporated to dryness at room temperature to yield a crude extracts. The extracts were stored at $-20^{\circ} \mathrm{C}$ till further use [7]. 
Table 1: List of plants used and their ayurvedic uses

\begin{tabular}{|c|c|c|c|c|}
\hline Plant name & $\begin{array}{l}\text { Voucher } \\
\text { specimen no }\end{array}$ & Family name & Part used & Ayurvedic/traditional use and reference \\
\hline $\begin{array}{l}\text { D. muricata } \\
\text { (Lesua) }\end{array}$ & $125 / 2012$ & Amaranthaeceae & Leaves & $\begin{array}{l}\text { Used for treatment of kidney stone and urinary tract } \\
\text { disorder [6] }\end{array}$ \\
\hline $\begin{array}{l}\text { A. pungens } \\
\text { (Khaki) }\end{array}$ & $126 / 2012$ & Amaranthaeceae & Whole plant & Diuretic properties, gonorrhea [8] \\
\hline $\begin{array}{l}\text { G. celosioides } \\
\text { (prostrate globe - amaranth) }\end{array}$ & $127 / 2012$ & Amaranthaeceae & Whole plant & Liver disease [9] \\
\hline $\begin{array}{l}\text { S. quitoense } \\
\text { (Naranjilla) }\end{array}$ & $128 / 2012$ & Solanaceae & Fruits & To make beverages, also have nutritional value [10] \\
\hline $\begin{array}{l}\text { I. pesticides } \\
\text { (Panchpatia) }\end{array}$ & $156 / 2013$ & Convolvulaceae & Leaves & Treatment of skin disorder \\
\hline $\begin{array}{l}\text { C. colocynthis } \\
\text { (Bitter cucumber) }\end{array}$ & $157 / 2013$ & Cucurbitaceae & $\begin{array}{l}\text { Fruit and whole } \\
\text { plant }\end{array}$ & $\begin{array}{l}\text { As most violent purgative drug, as energy source and as } \\
\text { oilseeds [11] }\end{array}$ \\
\hline $\begin{array}{l}\text { H. annuus } \\
\text { (Sunflower) }\end{array}$ & $158 / 2013$ & Asteraceae & $\begin{array}{l}\text { Seeds, leaves, } \\
\text { roots }\end{array}$ & Antioxidant, anti-inflammatory and diuretic properties [12] \\
\hline $\begin{array}{l}\text { L. aspera } \\
\text { (Goma madhupati) }\end{array}$ & $159 / 2013$ & Labiatae & Flower and root & $\begin{array}{l}\text { External application mostly for skin snake bite and } \\
\text { wounds [13] }\end{array}$ \\
\hline
\end{tabular}

D. muricata: Digera muricata, A. pungens: Alternanthera pungens, G. celosioides: Gomphrena celosioides, S. quitoense: Solanum quitoense, I. pesticides: Ipomoea pesticides,

C. colocynthis: Citrullus colocynthis, H. annuus: Helianthus annuus, L. aspera: Leucas aspera

\section{Preparation of inoculum}

Using aseptic techniques, bacterial culture was transferred in $100 \mathrm{ml}$ nutrient broth and incubated overnight at $37^{\circ} \mathrm{C}$. After $15-18 \mathrm{hrs}$ of incubation, the culture was centrifuged at 4,000 rpm for 5 minutes, the supernatant was discarded, and a clean sample of bacteria was prepared. The pellet was re-suspended using $20 \mathrm{ml}$ of double distilled water and centrifuged again at 4,000 rpm for 5 minutes. This step was repeated until the supernatant becomes clear. The optical density of that bacterial suspension was measured spectrophotometrically at $600 \mathrm{~nm}$, and serial dilutions were made till the optical density becomes 0.6 . The actual numbers of colony forming units were determined from the viability graph. The required dilution factor was calculated and the dilution made to obtain a concentration of $10^{6}$ cells $/ \mathrm{ml}$.

\section{In vitro antibacterial screening}

Antibacterial activities of the extracts were determined by the microbroth dilution assay in 96-well culture plates [14]. Stock solution of $50 \mathrm{mg} / \mathrm{ml}$ concentration was prepared in dimethyl sulfoxide (DMSO) or sterile water (the hexane/petroleum ether, chloroform plant extracts are dissolved in $10 \%[\mathrm{v} / \mathrm{v}]$ DMSO, acetone and methanol extracts of plants are dissolved in 5\% [v/v] DMSO). Autoclaved nutrient broth $(100 \mu \mathrm{l})$ was added to the wells of the culture plates, and the first row of microtiter plate was filled with $100 \mu \mathrm{l}$ of the test material. Two-fold serial dilutions of test extracts were made. $20 \mu \mathrm{l}$ of $2 \mathrm{X}$ resazurin solutions was added as an indicator in each well. Finally, a volume of $10 \mu \mathrm{l}$ was taken from bacterial suspension and then added to each well to achieve a final concentration of $5 \times 10^{6} \mathrm{CFU} / \mathrm{ml}$. To avoid the dehydration of bacterial culture, each plate was wrapped loosely with cling film. The experiment was run in duplicate. Proper controls were kept for each experiment. The plates were incubated at $37^{\circ} \mathrm{C}$ and examined for change in color after $18 \mathrm{hrs}$ for the growth of test bacteria. The extract was considered to be active if the wells appear clear without any visible growth of bacteria and the result is expressed as minimum inhibitory concentration (MIC).

\section{Pyocyanin inhibition assay}

Pyocyanin quantification was done by chloroform extraction method [15]. Cultures were treated with plant extracts having maximum MIC grown in triplicates and pyocyanin assay was also run in triplicate. P. aeruginosa was incubated with plant extracts for different time periods ( $8 \mathrm{hrs}, 10 \mathrm{hrs}$, and $12 \mathrm{hrs}$ ). Three sets of 18 cultures tubes were prepared having $4.5 \mathrm{ml}$ sterilized nutrient broth in each. To these tubes, $0.5 \mathrm{ml}$ plant extract (concentration having half of MIC) was added. Three sets of control culture tubes were also prepared having $5 \mathrm{ml}$ broth in each tube. To each tube, $20 \mu \mathrm{l}$ of bacterial inoculum was added. After incubation for indicated time periods, cultures were centrifuged at $10000 \mathrm{rpm}$ for 10 minutes, and the supernatant was collected. To $5 \mathrm{ml}$ supernatant $3 \mathrm{ml}$ of chloroform was added and vortexed for 20 seconds. The samples were centrifuged for 10 minutes at $5000 \mathrm{rpm}$, and $3 \mathrm{ml}$ of the resulting blue layer formed at the bottom (chloroform + pyocyanin) is transferred to a new tube. $2 \mathrm{ml}$ of $0.2 \mathrm{M}$ $\mathrm{HCl}$ was added to each tube and vortexed for 20 seconds. The sample was again centrifuged for 2 minutes at $5000 \mathrm{rpm}$, and $1 \mathrm{ml}$ of the pink layer is transferred to the cuvettes. $\mathrm{HCl}(0.2 \mathrm{M})$ is used as a blank. Spectrophotometric measurements were done at $520 \mathrm{~nm}$. Pyocyanin concentration $(\mu \mathrm{g} / \mathrm{ml})$ is calculated by multiplying the $\mathrm{OD}$ value at $520 \mathrm{~nm}$ with 17.072 .

\section{RESULTS AND DISCUSSION}

Yield $\%$ of plant extracts is given in Table 2 the text.

\section{Antibacterial activity}

About 40 extracts of eight plants were screened for their antimicrobial potential against $P$. aeruginosa, and six plants were found to exhibit considerable MIC. MIC of all the extracts is given in Table 3.

Ampicillin and Streptomyces were used as positive control shows MIC 125 and $250 \mu \mathrm{g} / \mathrm{ml}$, respectively. L. aspera has been reported to treat skin infections, snake bite, and wound healing was also found to be inactive against $P$. aeruginosa. The $H$. annuus was also found to be inactive against $P$. aeruginosa. Ipomoea pesticides showed week MIC in the range $6.25-12.5 \mathrm{mg} / \mathrm{ml}$ in accordance with its use in traditional medicine. Interestingly, D. muricata and Solanum quitoense were never reported for antimicrobial activity in traditional medicine or elsewhere exhibited strong antimicrobial activity. Hexane extracts of the plants exhibited the highest potential while chloroform and acetone extracts have considerable MIC. Aqueous extracts were not found to have antimicrobial activity. The acetone and methanol extracts of the plants exhibited MIC in the range of $1.56-6.25 \mathrm{mg} / \mathrm{ml}$ were further used for pyocyanin inhibition assay.

\section{Pyocyanin inhibition}

Recent reports showed that pyocyanin provides strong support to increase the virulence of $P$. aeruginosa. Various in vitro studies demonstrated that pyocyanin interferes with multiple cellular functions. Therefore, devising strategies to inhibit pyocyanin biosynthesis and neutralize its toxicity may be helpful in the treatment of cystic fibrosis and other infections caused by $P$. aeruginosa. In this study, pyocyanin was quantified in control and cultures of $P$. aeruginosa treated with sub-MIC of antimicrobial extracts. Pyocyanin concentrations found in control and acetone and methanol extracts treated cultures (at different time period) are given in Table 4. 
Table 2: Yield \% of plant extracts

\begin{tabular}{|c|c|c|c|c|c|}
\hline Plant extract & Hexane yield \% & Chloroform yield \% & Acetone yield \% & Methanol yield \% & Water yield \% \\
\hline D. muricata & 0.072 & 1.67 & 1.68 & 7.42 & 18.01 \\
\hline A. punguns & 0.17 & 0.42 & 0.56 & 3.44 & 1.750 \\
\hline G. celosioides & 0.2 & 1.10 & 0.61 & 4.11 & 4.34 \\
\hline S. quitoense & 0.2 & 0.315 & 2.33 & 1.027 & 1.236 \\
\hline I. pesticides & 0.17 & 1.95 & 0.6 & 2.94 & 3.5 \\
\hline C. colocynthis & 1.55 & 3.124 & 3.34 & 13.78 & 6.45 \\
\hline H. annuus & 0.2 & 1.82 & 2.15 & 6.29 & 11.81 \\
\hline
\end{tabular}

D. muricata: Digera muricata, A. pungens: Alternanthera pungens, G. celosioides: Gomphrena celosioides, S. quitoense: Solanum quitoense, I. pesticides: Ipomoea pesticides,

C. colocynthis: Citrullus colocynthis, H. annuus: Helianthus annuus, L. aspera: Leucas aspera

Table 3: MIC (mg/ml) of plant extracts of against P. aeruginosa $(-)$ represents the absence of activity in the respective plants

\begin{tabular}{llllll}
\hline Plant extract & Hexane $(\mathbf{m g} / \mathbf{m l})$ & Chloroform $\mathbf{( m g} / \mathbf{m l})$ & Acetone $(\mathbf{m g} / \mathbf{m l})$ & Methanol $(\mathbf{m g} / \mathbf{m l})$ & Water $(\mathbf{m g} / \mathbf{m l})$ \\
\hline D. muricata & 0.781 & 1.56 & 1.56 & 6.25 & 12.5 \\
A. punguns & 3.125 & 3.125 & 3.125 & 6.25 & - \\
G. celosioides & 3.125 & 3.125 & 6.25 & 12.5 & - \\
S. quitoense & 1.56 & 1.56 & 1.56 & 12.5 & - \\
I. pesticides & 6.25 & 12.5 & 6.25 & - & - \\
C. colocynthis & 3.125 & 3.125 & 3.125 & 6.25 & - \\
H. annuus & 12.5 & 12.5 & 12.5 & 12.5 & - \\
L. aspera & 12.5 & 12.5 & 12.5 & 12.5 & - \\
\hline
\end{tabular}

P. aeruginosa: Pseudomonas aeruginosa, D. muricata: Digera muricata, A. pungens: Alternanthera pungens, G. celosioides: Gomphrena celosioides, S. quitoense: Solanum quitoense, I. pesticides: Ipomoea pesticides, C. colocynthis: Citrullus colocynthis, H. annuus: Helianthus annuus, L. aspera: Leucas aspera, MIC: Minimum inhibitory concentration

Pyocyanin production was found to be inhibited in treated cultures with I. pesticides, D. muricata, and G. celosioides acetone extracts as compared to control cultures after $8 \mathrm{hrs}$. Whereas, A. pungens, S. quitoense, and C. colocynthis inhibited pyocyanin production after $10 \mathrm{hrs}$ surprisingly, G. celosioides and I. pesticides extracts which initially did not exhibit any effect, found to be most effective to block pyocyanin biosynthesis to 0.00 and $0.0239 \mu \mathrm{l} / \mathrm{ml}$ after $10 \mathrm{hr}$ incubation. D. muricata which exhibited best MIC among the plants studied did not block pyocyanin synthesis as compared to other plants.

Methanol extracts of A. punguns D. muricata, and C. colocynthis exhibited better MIC, therefore, pyocyanin was estimated in cultures treated with Sub-MIC of these extracts. Methanol extract of C. colocynthis exhibited better inhibition at $8 \mathrm{hrs}$. Cultures treated with these extracts found to have significantly depleted levels of pyocyanin after $12 \mathrm{hrs}$ incubation (Table 4). Comparison of all these activities is shown in graph (Fig. 1).

Overall, results indicate that blockage of pyocyanin synthesis and bacterial growth inhibition is the separate processes. The best antimicrobial compound may not be best the inhibitor of pyocyanin biosynthesis or vice-versa. Moreover, I. pesticides, C. colocynthis, and D. muricata seem to contain compounds which inhibit the growth of bacteria as well as the biosynthesis of pyocyanin. Extracts found active can be further explored to search active molecules which can be screened for combinatorial therapies with antibiotics to incorporate into existing regimens for the treatment against P. aeruginosa.

\section{CONCLUSION}

This report is the first comprehensive study of herbal inhibition of pyocyanin in $P$. aeruginosa. Interestingly, inhibition of pyocyanin synthesis and bacterial growth is the separate processes. The best antimicrobial compound may not be best inhibitor of pyocyanin biosynthesis or vice-versa. Among all acetone extracts of selected plants, D. muricata and S. quitoense exhibited significant antibacterial activity but does not showed best pyocyanin inhibition. This study gives a preliminary idea for extraction of the new active compound and use of these plants in combination with antibiotics to combat antibiotics resistance against $P$. aeruginosa.
Table 4: Pyocyanin quantification in P. aeruginosa culture treated with acetone and methanol plant extracts by chloroform extraction method

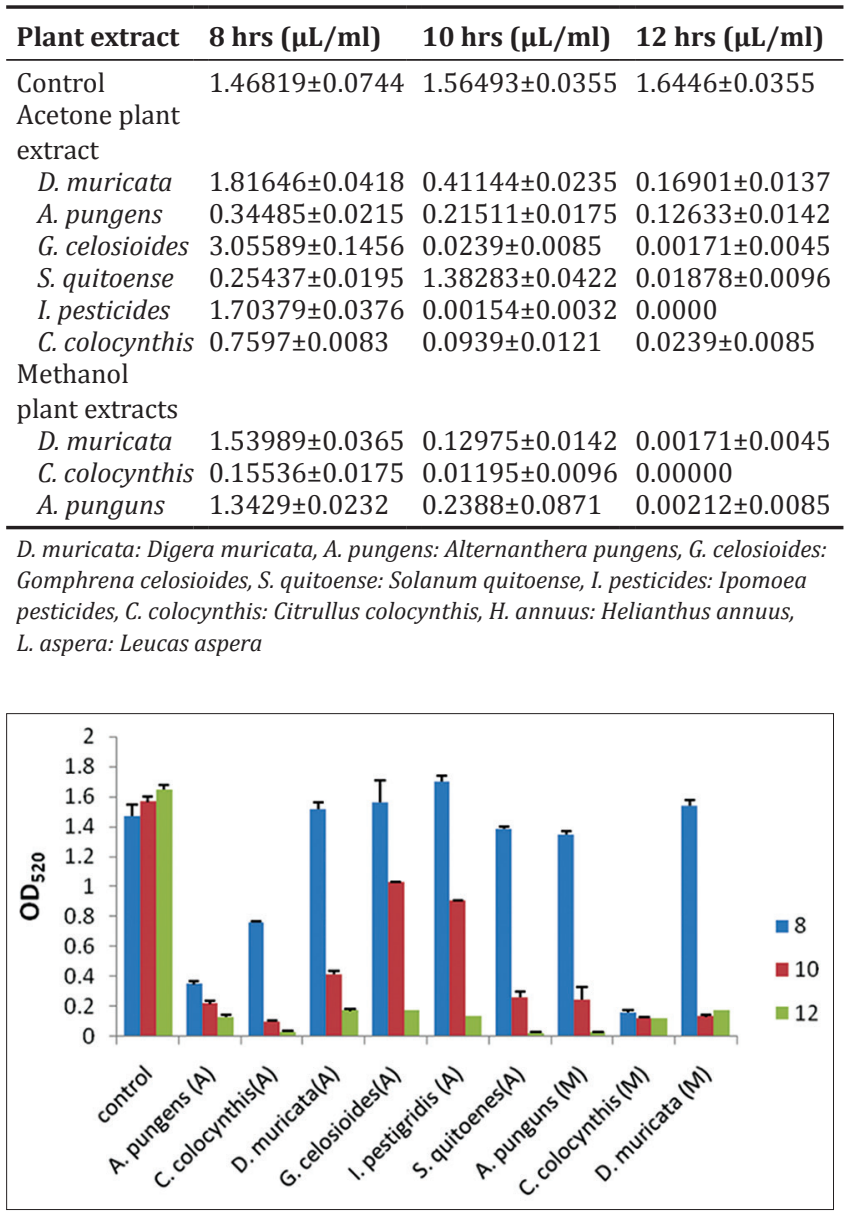

Fig. 1: Comparison of pyocyanin inhibition activities of different plants 


\section{REFERENCES}

1. Marshall BC, Carroll KC. Interaction between Pseudomonas aeruginosa and host defenses in cystic fibrosis. Semin Respir Infect 1991;6(1):11-8.

2. Gupta MP, Solis PN, Calderón AI, Guinneau-Sinclair F, Correa M, Galdames C, et al. Medical ethnobotany of the tribes of Bocas del Toro. Panama. J Ethnopharmacol 2005;96:389-401.

3. Cox CD. Role of pyocyanin in the acquisition of iron from transferrin. Infect Immun 1986;52(1):263-70.

4. Ran H, Hassett DJ, Lau GW. Human targets of Pseudomonas aeruginosa pyocyanin. Proc Natl Acad Sci U S A 2003;100(24):14315-20.

5. Diggle SP, Winzer K, Chhabra SR, Worrall KE, Cámara M, Williams P. The Pseudomonas aeruginosa quinolone signal molecule overcomes the cell density-dependency of the quorum sensing hierarchy, regulates rhl-dependent genes at the onset of stationary phase and can be produced in the absence of LasR. Mol Microbiol 2003;50(1):29-43.

6. Irda $\mathrm{F}$, Evelyne $\mathrm{N}$, Komar RW. In vitro antioxidant activities, total flavonoid, phenolic and carotenoid content from various extracts of four species Asteraceae herb. Int J Pharm Pharm Sci 2017;7:192-7.

7. Katiyar D, Singh V, Ali M. Isolation, characterization and prediction of biological activity of two new fatty esters and a phenol from the heartwood of Pterocarpus marsupium roxb. Int J Pharm Pharm Sci 2017;9:117-22.
8. Kopec DM, Gilbert J, Pessarakli M. Penoxsulam as a Potential Post-Emergence for Khakiweed (Alternanthera pungens). 2004. Available from: http://www.cals.arizona.edu/pubs/crops/az1359.

9. Onocha PA, Ajaiyeoban EO, Dosumu OO, Ekundayo O. Phytochemical screening and biological activities of Gomphrena celosioides (C. Mart.) extracts. Nigerian Soc Exp Biol J 2005;5:59-65.

10. Gancel AL, Alter P, Dhuique-Mayer C, Ruales J, Vaillant F. Identifying carotenoids and phenolic compounds in Naranjilla (Solanum quitoense Lam. var. Puyo hybrid), an andean fruit. J Agric Food Chem 2008;56:11890-9.

11. Rai MK. A review on some antidiabetic plants of India. Anc Sci Life 1995;14(3):168-80.

12. Putt ED. Early history of sunflower. Sunflower Technol Prod 1997;35:1-19.

13. Prajapati MS, Patel JB, Modi K, Shah MB. Leucas aspera: A review. Pharmacogn Rev 2010;4(7):85-7.

14. Khond M, Bhosale JD, Arif T, Mandal TK, Padhi MM, Dabur R. Screening of some selected medicinal plants extracts for in-vitro antimicrobial activity. Middle East J Sci Res 2009;4:271-8.

15. Essar DW, Eberly L, Crawford IP. Evolutionary differences in chromosomal locations of four early genes of the tryptophan pathway in fluorescent pseudomonads: DNA sequences and characterization of Pseudomonas putida trpE and trpGDC. J Bacteriol 1990;172(2):867-83. 